\title{
Virtuelle portfolier som bedømmelses- og læringsredskab
}

\author{
Annette Skov \\ Studielektor \\ Institut for Informationsstudier \\ Danmarks Biblioteksskole \\ as@db.dk \\ http://www.db.dk/as/home1_dk.htm
}

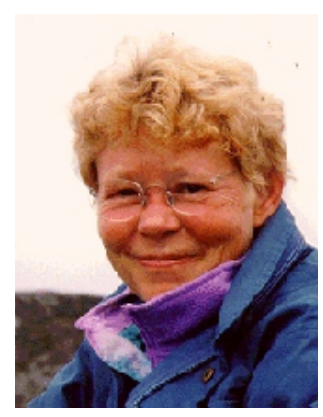

\section{Lennart Björneborn}

Lektor, ph.d.

Institut for Informationsstudier

Danmarks Biblioteksskole

$\underline{\mathrm{lb} @ \mathrm{db} . \mathrm{dk}}$

http://www.db.dk/lb

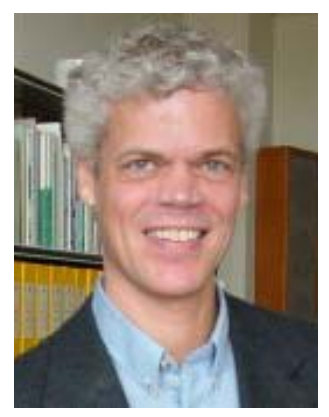

Annette Skov er studielektor ved Institut for Informationsstudier ved Danmarks Biblioteksskole i København. Hun beskcftiger sig med udvikling af undervisning, og underviser bl.a. i informationssøgning, læring, pæedagogik og informationskompetence.

Lennart Björneborn er lektor, ph.d., ved Institut for Informationsstudier ved Danmarks Biblioteksskole i København. Han forsker og underviser bl.a. i, hvordan opbygning af informationssystemer, især WWW og biblioteker, kan understøtte involvering af brugere, videndeling og serendipitet (uplanlagte informationsfund).

\section{Indledning}

Artiklen tager udgangspunkt i to cases i form af to undervisningsforløb på bacheloruddannelsens 5. semester på Danmarks Biblioteksskole: "Biblioteker, læring og informationskompetence” og "På tværs af WWW”, hvor vi har benyttet portfolio-metoden.

Vores ideer om kvalitet i undervisning og bedømmelsesprocedurer er inspireret af John Biggs" ”constructive alignment” (Biggs, 2003) og Paul Ramsdens læringsstrategier (Ramsden, 1999). Det afgørende for os er derfor, at læringsmål, undervisningsformer og bedømmelsesprocedurer arbejder mod samme mål og fremmer de studerendes dybdelæring.

Artiklens hovedbudskab er, at portfolio-metoden er den mest tilfredsstillende bedømmelsesform, forfatterne har været involverede i. Den har en høj grad af validitet, idet den måler de studerendes læring, og det er meget tilfredsstillende, at eksamensformen er en integreret del af 
læreprocessen. Arbejdet bliver spredt over semestret, og hele forløbet får karakter af en proces, hvor de studerendes refleksioner over faget og egen læring får en central placering.

\section{Case 1: Kurset "Biblioteker, læring og informationskompetence"}

Den ene af forfatterne (AS) benyttede portfolioafløsning som bedømmelsesform på valgkurset "Biblioteker, læring og informationskompetence" (60 timer), som fandt sted i efteråret 2004. Indholdselementerne i kurset var læringsteorier, læringsstile og intelligenser, informationskompetence, informationssøgeprocessen som læreproces, læring i det virtuelle rum og undervisningsteknik og -formidling.

Kurset havde en række principper for design af læringsrummet; der skulle være overensstemmelse mellem form og indhold, dvs at kurset skulle eksemplificere læringsteorien. Når udgangspunktet er konstruktivistisk læringsteori, skal dette selvfølgelig afspejles i de studerendes læringsaktiviteter. Studier af teorier er godt, men afprøvning af teorierne i praksis er endnu bedre. Kurset skulle være et refleksivt rum, der indbød til meta-læring. Ligeledes skulle kurset give de studerende en række vigtige sidekompetencer såsom social kompetence, kommunikativ kompetence, proceskompetence og problemløsningskompetence. Desuden skal kommende bibliotekarer kunne færdes i et virtuelt univers, så kompetencer i design af websider og computermedieret kommunikation er centrale. Endelig var det vigtigt, at der var sammenhæng mellem eksamen, arbejdsformer og undervisningsmål.

Kurset var bygget op omkring to projekter. Det første af disse havde titlen ”Arrangér en todages konference om bibliotekets rolle i de studerendes læring”. De studerende blev inddelt i grupper på fem efter læringsstile og fik en introduktion til problembaseret læring (PBL) og til mind mapping-teknikker. Feltpraktikbesøg hos reflekterende praktikere var en vigtig del af forløbet.

Det blev desuden understreget, at konferencen skulle være "en lærende konference” med et klart fokus og ikke en samling løsrevne oplæg. Projektafleveringen bestod af en ansøgning til en sponsor, et skriftligt konferenceprogram med abstracts af de enkelte indlæg og en annoteret litteraturliste over konferencens emner ledsaget af en mundtlig fremlæggelse.

Emnet for det andet projekt var selvvalgt, og de studerende dannede selv projektgrupper efter interesse. Flere af grupperne valgte at fortsætte samarbejdet fra de "tvungne” projektgrupper, da PBL havde givet dem et redskab, der fik gruppen til at fungere. Projektafleveringen af det andet projekt bestod også af en skriftlig opgave med mundtlig fremlæggelse.

\section{Portfolioens indhold}

De studerende fik følgende instruks om udarbejdelsen af portfolioen:

"I skal hver især oprette en digital portfolio (arbejdsportfolio) på jeres område på studenterserveren. På dette netsted lægger I følgende:

- jeres personlige logbog over faglige problemstillinger og egen læring,

- de projektopgaver, I er med til at udarbejde med angivelse af jeres eget bidrag,

- jeres refleksionsnotater (proces-log),

- jeres personlige ressourcer, $\mathrm{fx}$ gode netsteder, artikler.

I slutningen af forløbet skal jeres præsentationsportfolio bestå af:

- 2 bidrag til projektarbejde (1. og 2. delafløsning),

- 3 refleksionsnotater med følgende indhold: - personlig startrefleksion (forudsætninger, motivation, forventninger, mål) (1/2 A-4 side), 
- refleksionsnotat i forbindelse med delafløsning 1 (kan handle om gruppesammensætning efter læringsstile eller om at arbejde efter PBL,1 A-4 side), - personlig slutrefleksion (konklusionen på løbende refleksioner over faglige problemstillinger og egen læring - indsats, udbytte og perspektiver) (1 A-4 side)”.

De studerende oprettede deres portfolier på en af skolens webservere, som regel med FrontPage som redigeringsværktøj. De studerende, som ikke var interesserede i få deres opgaver og refleksioner tilgængeliggjort på nettet, forsynede deres web med et no index, no follow meta-tag.

Der blev oprettet en fælles kursusweb med links til de studerendes portfolier, og de blev opfordret til at læse hinandens refleksioner og opgaver og give hinanden feedback. Kursuswebben blev forsynet med et 'robot exclusion' meta-tag for at forhindre søgemaskiner $\mathrm{i}$ at indeksere indholdet,

\section{Det refleksive element}

Hvis en portfolio skal være et redskab for læring, er det refleksive element vigtigt - uden det er portfolio-metoden blot en samling delopgaver. De studerendes refleksioner giver også et væsentligt input til underviseren igennem hele forløbet. Især har det været spændende at læse de studerendes startrefleksioner: hvad er deres forudsætninger, erfaringer og motivation? Hvad er det, vi skal bygge videre på i forløbet? En startrefleksion bevirker, at de studerende træder i karakter som individer fra kursets begyndelse.

Efter at de studerende havde lagt deres startrefleksion ind i deres portfolio, fik de følgende kommentar med på vejen i form af et indlæg på kursuswebbens nyhedsside:

”Tak for jeres refleksioner, det er spændende læsning.

I stedet for at kommentere individuelt vil jeg komme med nogle generelle betragtninger. Jeg har ikke før prøvet at bede studerende om at skrive en startrefleksion, og jeg har været spændt på resultatet. Jeg har selvfølgelig nogle ideer med startrefleksionen:

At kunne reflektere over sin egen læring er en grundkompetence, som er forudsætningen for livslang læring. Det er selvfølgelig et mål i sig selv. Desuden er startrefleksionen første trin i en proces, som slutter, når I skriver jeres slutrefleksion: hvad har jeg lært i forhold til det, jeg gerne ville lære, levede forløbet op til mine forventninger, har jeg nået mine personlige mål? At have gjort sig nogle tanker indledningsvis skulle gerne gøre processen mere målrettet og bevidst.

Mads Hermansen (ham med "læring kræver møje" og "frustrationsrobusthed") har sagt noget andet klogt: "Undervisning handler om at få krog i den enkelte studerendes tilværelsesprojekt (det et bevidst og frit villende væsen har for med sin tilværelse)”.

Jeg forestiller mig, at et refleksionsnotat kunne medvirke til, at hver enkelt blev tvunget til at overveje: har det, jeg skal lære overhovedet nogen betydning for mig i det, jeg vil med mit liv? 
Det gør også indtryk på mig som underviser at I kommer på banen som voksne mennesker med en række værdifulde erfaringer og overvejelser - i stedet for at være ”hende eller ham nede i hjørnet, som en gang imellem rækker fingeren op”.

Desuden viser refleksionerne også klart en vigtig pointe i konstruktivistisk læring: at I har forskellige erfaringer og videnstrukturer i forhold til emnet, som I hver især bygger videre på - I vil aldrig lære helt det samme!”

\section{Bedømmelse af portfolioen}

Startrefleksionen indgik ikke i den samlede bedømmelse af portfolioen. Bedømmelsesprocedurer er udformet til at måle, hvorvidt den studerende har opnået det forventede læringsudbytte. De kan ikke anvendes til at vurdere indledende refleksioner over erfaringer, forventninger, motivation og mål.

Delopgaverne blev bedømt ved hver deadline; og denne formative evaluering blev givet i form af en mundtlig feedback til hele holdet. Underviseren udvalgte en række temaer til fælles diskussion og refleksion, fx "hvad kan det skyldes, at nogle af jer har haft stort udbytte af at arbejde i grupper sammensat efter læringsstile, mens andre mener, at det ikke er særlig givtigt?” Et par studerende fik desuden besked på at forbedre deres præstationer.

Den summative evaluering blev foretaget på baggrund af portfolioen og den mundtlige fremlæggelse af den sidste projektopgave. Læringsmålene - og dermed bedømmelseskriterierne var meldt klart ud fra starten af kurset. Især blev det betonet, at det refleksive element blev vægtet højt. Alle studerende fik karakteren "Godkendt” for deres indsats. Bedømmelsen blev meddelt umiddelbart efter den mundtlige fremlæggelse.

\section{De studerendes vurdering}

De studerendes vurdering af portfolio-formen var meget positiv. De refleksive og procesorienterede elementer har gjort indtryk, og det har haft stor betydning for dem at have et "hjemsted" for deres arbejder, tanker og refleksioner i form af en virtuel portfolio. Flere studerende har ud over det krævede lavet weblogs, hvor de løbende har funderet over deres læring.

Følgende er citater fra de studerendes slutevalueringer:

"I starten af faget var jeg lidt frustreret over den digitale portfolio, da jeg aldrig har skullet lave min egen hjemmeside før, og heller aldrig løbende har lavet skriftlige refleksioner over et fag. Nu da faget er ved vejs ende, synes jeg, det er en af de ting, jeg har haft størst glæde af undervejs. Da jeg først kom i gang med hjemmesiden, var det sjovt at opleve, hvor nemt det egentlig var. Det refleksive har jeg også haft meget glæde af. Selvom det kun var de tre refleksioner, vi skulle skrive, var det alligevel noget, der hele tiden lå i baghovedet. Det gjorde, at jeg blev mere bevidst om, hvad vi lærte og hvad det kunne bruges til, og hvor stor en rolle det refleksive spiller i læreprocessen.”

"Faget har gjort mig mere bevidst om min egen læreproces og fået mig til at tænke en del over hvordan jeg lærer. At vi gennem hele forløbet har skullet reflektere en hel del har gjort mig opmærksom på hvor vigtig en del af læreprocessen det er. Det har fået mig til at tænke refleksion ind i mange andre sammenhænge, ikke mindst fagligt. Det har været udfordrende at skulle lave en hjemmeside. I starten synes jeg måske det var lidt tilovers, men nu jeg er glad for at det var påkrævet. Nogle gange skal man tvinges lidt og det har været sjovt at eksperi- 
mentere. Jeg kunne godt tænke mig at have brugt mere tid på arbejdet med hjemmesiden, end jeg har haft mulighed for.”

Kurset blev desuden evalueret som et led i Biblioteksskolens normale evalueringsprocedure. (Spørgeskemaundersøgelse med kommentarmulighed).

\section{Case 2: Kurset "På tværs af WWW"}

Den anden af forfatterne (LB) valgte at integrere portfolioafløsningen i det projektorienterede valgkursus "På tværs af WWW" på 5. semester i efteråret 2004. Kurset indledtes med 30 undervisningstimer, der gav indføring i forskellige temaer inden for vidensorganisering, videndeling og informationssøgning på WWW. Efterfølgende på kurset arbejdede de 20 studerende projektorienteret med problemstillinger med udgangspunkt i ovenstående temaer. Projektforløbet blev eksamineret ved afløsning i form af en skriftlig portfolio-afløsning med mundtlig fremlæggelse.

På samme semester fulgte de studerende et andet valgkursus, hvor de skulle skrive en studieopgave med ekstern censur.

\section{Portfolioens indhold}

Hver studerende oprettede et websted på biblioteksskolens studerende-server, der skulle fungere som deres personlige portfolio-web. De studerende blev opfordret til at arbejde kreativt med layoutet af webstedet i løbet af kurset. De fleste studerende brugte FrontPage som redigeringsværktøj. I figur 1 vises et eksempel på en af de studerendes portfolio-webs.

\section{Lenas webportfolio}

\section{På tværs af WWW:}
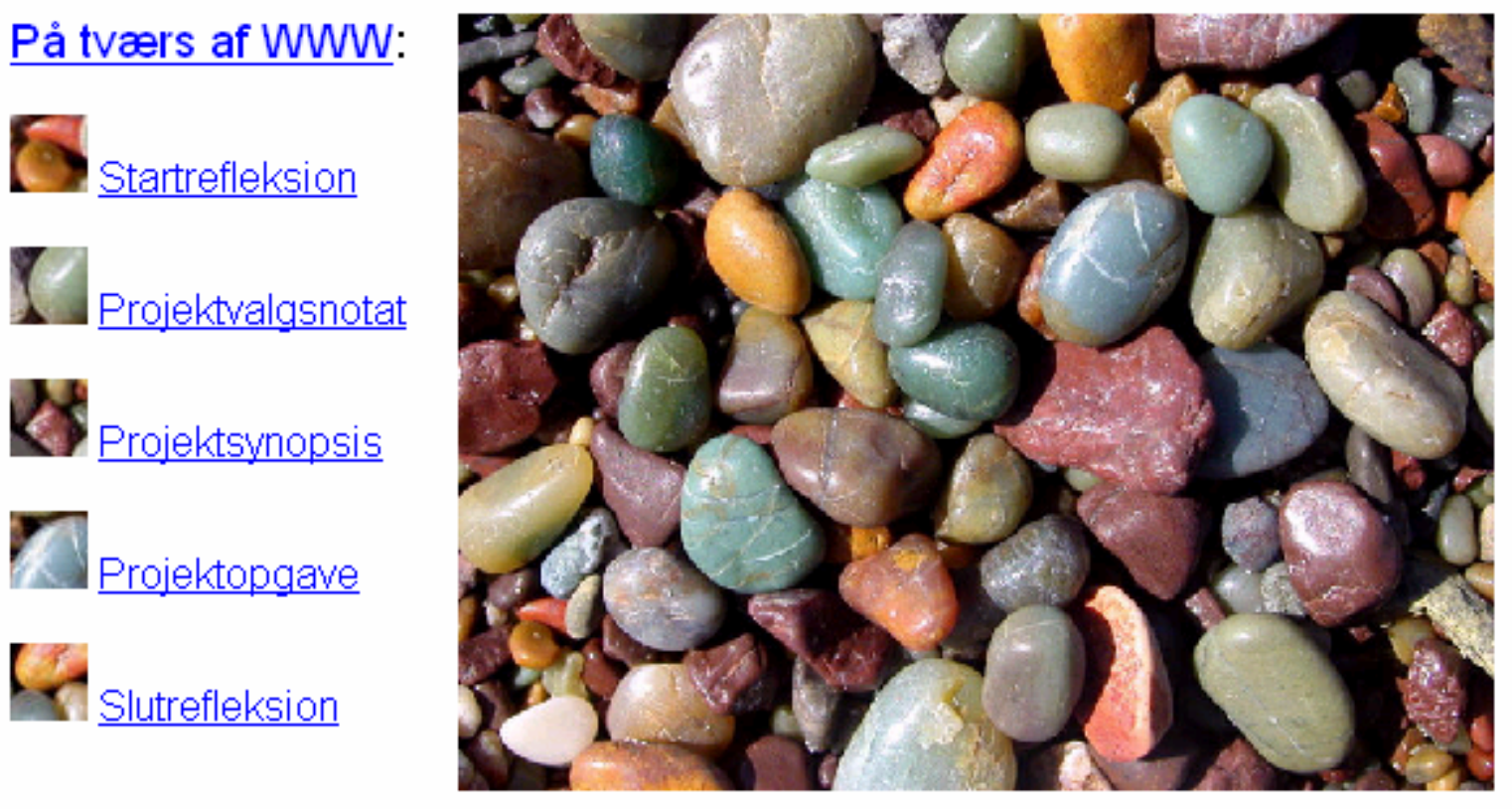

Figur 1. Eksempel på en studerendes portfolio-web. (Anonymiseret navn). 
De studerendes portfolio-webs skulle i løbet af kurset inkludere følgende delopgaver:

- $\quad$ startrefleksion over personlige forudsætninger, motivation, forventninger, målsætning for læring (inkl. egen indsats) - ca. 200 ord - frist 15.9, dvs. 2 uger efter kursusstart,

- projektnotat - idéudkast til projektopgave; med indledning, motivation, foreløbig problemformulering og metodeovervejelser - ca. 700 ord - frist 20.10 lige efter efterårsferien,

- øvelse: blog - lave en weblog over gode websteder, projekt-idéer, refleksioner mm. der afspejler projektprocessen - frist 26.10 (der blev her brugt de brugervenlige skabeloner hos www.blogger.com).

- øvelse: wiki - lave en indførsel i en wiki (dvs. brugerredigeret websted som fx wikipedia.org, wikitravel.org) - også frist 26.10, (der blev her brugt de pågældende wikis egne indbyggede redigeringsfunktioner).

(Da nogle af de studerende lavede blogs og wiki-indførsler med meget private interesser, som de ikke nødvendigvis ville vise deres medstuderende, var det her frivilligt, om de ville lægge dem ind på deres portfolio-web),

- projektsynopsis - 'udvidet abstract' på ca. 1000 ord af hele projektopgaven 5 dage før fremlæggelse af opgaven, dvs. enten 26.11 eller 3.12,

- $\quad$ projektopgave - standardkrav til opgaver på DB - frist dagen før fremlæggelse, dvs. enten 30.11 eller 7.12,

- slutrefleksion over personlig indsats for egen læring, samt udbytte og perspektivering ift. fremtidig læring - ca. 400 ord - frist 10.12.

Projektnotat, projektsynopsis og endelig projektopgave kunne afleveres som gruppearbejde, hvis man ikke arbejdede alene. Hvis man arbejdede gruppevis, skulle hver gruppedeltager oprette en personlig portfolio med indhold som angivet ovenfor og med links til fælles delopgaver.

Der blev lavet en fælles indgangsside til de studerendes portfolio-webs, så de fik mulighed for at se hinandens bidrag. Som en af de studerende skrev i sin slutrefleksion:

"Det bedste ved denne form for evaluering, er efter min mening, at vi har mulighed for at læse de øvrige studerendes projekter. Det synes jeg at man får virkelig meget ud af, idet man får indsigt i emner eller områder man eller ikke ville være stødt på.”

Den fælles indgangsside og de studerendes portfolio-webs lå på skolens offentligt læsbare web-servere for at smidiggøre de studerendes adgang. I forbindelse med at der på kurset var en diskussion om grænser for, hvor synlig man ønsker at være på webben, blev der i øvrigt lagt en 'robot exclusion' ind som meta-tag på ovennævnte fælles indgangsside, for at forhindre søgemaskiner i at indeksere de studerendes portfolio-webs med opgaver og personlige refleksioner, da flere af de studerende syntes, at der var for personlige eller ufærdige ting lagt ud på deres webs.

Delopgaverne blev bedømt undervejs af underviseren ved hver deadline. Kun to gange var en delopgave så utilfredsstillende, at den studerende per e-mail blev bedt om at lave en bedre og mere selvreflekterende delopgave. Alle de afsluttende projektopgaver blev godkendt (meddelt via skolens studieadministration). To skriftlige opgaver lå dog lige på grænsen til at blive underkendt, men blev hevet op til godkendt, dels af den mundtlige fremlæggelse, dels af den studerendes andre portfolio-delopgaver, der var så tilfredsstillende, at den samlede helhedsbedømmelse af portfolioen inkl. projektopgave mundede ud i en godkendelse. 
De fleste af de 20 studerende på holdet valgte at arbejde i grupper med deres projekter. De tre største af grupperne med 4 og 5 studerende lavede alle projekt-blogs - som spin-off af at de havde haft øvelser i at lave blogs - hvor de hurtigt kunne dele og holde styr på projektideer, links, referencer, mm. med hinanden og samtidig få hurtigt overblik. En sådan gruppeprojektblog viste sig at være et rigtig godt proces-værktøj. Som en af de studerende skriver i sin slutrefleksion:

"Den weblog vi etablerede i forbindelse med gruppearbejdet har fungeret som et ideelt og uundværligt værktøj, som jeg helt klart vil anvende i en anden gruppesammenhæng.”

\section{De studerendes vurdering}

De studerendes vurdering af portfolio-formen var meget positiv. De så det som et godt redskab til at holde i gang projektprocessen og reflektere over deres egen læring, hvilket nogle udpluk fra studerendes slutrefleksioner og evalueringer viser:

"Portfolion har fungeret fint og har holdt en i gang. Har krævet et vist eget ansvar og engagement, hvilket er godt!”

"Portfolioen har lettet vores arbejde med hensyn til projektopgaven, idet dette har krævet en vis planlægning af vores arbejdsindsats i forhold til deadlines.”

”Portfolion är en mycket bra idé och jag gillade att behöva reflektera över mitt eget lärande på kursen (det har jag aldrig behövt göra i skriftlig form innan). Det var en hjälp att formulera i ord vad man vill ha ut av kursen när man börjar och att veta att det ska följas upp i en slutreflexion. Det var också kul att ha en möjlighet att se hur de andra studenterna på kursen arbetade! Det passade mig bra att ha deadlines löpande under terminen med små inlämningsuppgifter och annat, även om det ibland kunde kännas stressigt... Det var skönt att se att man avklarade saker och inte hade allt kvar till slutet av terminen.”

Der deltog to svenske udvekslingsstuderende på kurset. Den enes refleksioner indgår i udplukket ovenfor. Nedenfor gengives den anden svenske studerendes slutrefleksion i sin helhed, da den giver et fint indblik i, hvordan portfolioen åbner op for refleksioner omkring personlig indsats og udbytte med hensyn til egen læring, samt perspektivering i forhold til fremtidig læring. 


SlutreflekSiOn
Utifrăn de bristfälliga kunskaper som jag hade när jag började kursen "Pă tvaers af Whw"
tycker jag att jag kan se en skillnad idag vid kursens slut. Jag har bland annat fătt
kännedom om flera olika resurs- och användningsomrăden som jag troligtvis inte hade
kommit i kontakt med annars. När det till exempel gäller blogs och wikipedia har det varit
en ganska stor utmaning fär mig att vi pă kursen inte bara skulle veta att de existerade,
utan även prova pă att vara aktiva själva. Jag kände ett visst motstănd till att ge mig in i
detta eftersom jag kände mig väldigt okunnig, men efterăt var jag stolt! Att vi var "tvungna"
att prova pă saker själva gjorde att kunskapen blev ännu djupare. Jag har även upptäckt hur
roligt det är att skapa egna webbsidor! Det är för övrigt năgot som jag gärna vill lära mer om.
I början på terminen kände jag stor entusiasm inför kursen. Detta har i stort sätt inte
förändrats alls under terminen eftersom ämnet har förmedlats pă ett levande och personligt
sätt av văr lärare. Mitt măl med kursen var att jag ville fă en bra grund att stă pă inför mitt
kommande arbetsliv. Jag ville fă ökad förstăelse och kunskap och detta skulle ske genom
stor egen arbetsinsats (kurslitteratur, portfolio-uppgifter, uppsats). Jag tycker att min
arbetsinsats pă portfolio-uppgifterna (löpande under terminen) och uppsatsen har varit
ganska stor. Jag har lagt ned mycket tid och kraft pă dem och fătt med mig en hel del
erfarenheter och kunskaper som jag säkert kommer att ha nytta av. Min öwriga arbetsinsats
tycker jag har varit ok.
När jag nu slutar kursen känner jag mig väldigt nöjd eftersom jag fătt kunskap som jag inte
hade kunnat fă om jag inte hade valt att studera en termin i Köpenhamn som
utbytesstudent. Jag känner att jag faktiskt har fătt bättre grund att stă pă och att det som
jag tidigare tyckte fattades i min utbildning, nu finns där. Det känns som om det finns
oändligt mycket mera att lära inom ämnet, men min nyfikenhet är lika stor som innan
kursen (kanske t.o.m. större) och jag tror att jag har fătt redskap som kan hjälpa mig i mitt
fortsatta lärande.

Figur 2. Eksempel på slutrefleksion fra en studerende (jf. Figur 1).

De studerende syntes, at der var tilpas udfordringer i form af integrerede øvelser (bl.a. med at lave en ændring i en såkaldt wiki, dvs. brugerredigeret websted som fx wikipedia.org, wikitravel.org), der skulle klares undervejs og indgå i portfolioen:

”Underopgaverne i portfolioen har været forbavsende spændende. At pludseligt blive kastet ud i noget man på forhånd havde ingen eller meget lidt viden om har været lærerigt og udfordrende, og givet en mod på at prøve at gå videre.”

"Øvelserne har været gode, især i kraft af at vi skulle lægge dem ind på vores webside. Det gør at man gør lidt ekstra ud af det.”

Der var også tilfredshed med, at portfolioen skulle laves i web-form - og at man dermed nemt kunne følge med i, hvad de andre lavede. De studerende oplevede det også som positivt at udvikle nogle sidekompetencer i form af at skulle lave websider, da alle delopgaver skulle afleveres i denne form:

"Arbejdet med webportfolien og frontpage viste sig at være langt nemmere og rigtig meget sjovere at gå til, end jeg havde frygtet. Har egentlig gået og stresset lidt over at dette var et område, hvor jeg var temmelig blank (set i forhold til 
fremtiden). Så det er rigtig rart, at have fået det med i værktøjskassen til at arbejde videre med. Wiki-indførslen, webportfolien og bloggen er mit allerførste bidrag til materiale på nettet. Det var ganske grænseoverskridende i forhold at skulle "stikke snuden frem", hvilket bestemt ikke hører til mine stærke sider. Øvelserne har bestemt uddybet min fortrolighed og fremtidige brug af webben.”

”Jag upplever att arbetet med webbportfolien varit en mycket viktig del av detta. Jag har gjort något konkret, något att peka på. Jag kan se vad jag kan, vilket är både befriande och uppmuntrande när hela min studietid varit så teoretisk. Att få skapa något har stimulerat en kreativ och praktisk sida, som jag påminns om att jag saknar.”

"Rent konkret har portfolie-webben både været en god motivationsfaktor og et godt værktøj til at få noget praktisk erfaring med webben. Jeg føler selv, at jeg har formået at udvikle nogle kompetencer til hjemmeside-arbejde, selvom der er meget at lære endnu.”

”Det har været sjovt at oprette og vedligeholde en hjemmeside. Det var på ingen måde så besværligt, som jeg gav udtryk for i min startrefleksion. Jeg må blank indrømme, at jeg har fået blod på tanden omkring at udvikle en "rigtig’ side.”

Meta-aspektet - på et kursus om webben - med at de studerende selv skulle lave websider til deres personlige portfolio-webs fungerede altså rigtig godt. Det var dejligt at se, hvordan mange af de studerende fik blod på tanden til at lave websider fremover.

\section{Konklusion}

Portfoliobedømmelse er en meget tilfredsstillende bedømmelsesform, især i forbindelse med projektorienteret undervisning. De indbyggede refleksioner og delopgaver med deadlines er gode redskaber for de studerende til på en mere refleksiv vis at komme i gang med at tænke i projektbaner og ikke mindst holde gang i disse projekter, i stedet for at gemme al krudtet til lige før aflevering, som ofte ses ved andre eksamensformer. Bedømmelsesformen er procesorienteret og giver mulighed for både formativ og summativ vurdering. Især den formative feedback er væsentlig, fordi den kan bruges fremadrettet i dialogen mellem de involverede parter i læringsrummet. Den summative bedømmelse er mere omfattende og repræsentativ, idet den ikke tager udgangspunkt i en enkelt "knald eller fald” præstation, men måler den studerendes læringsudbytte over en længere periode. Eksamensformen bliver på den måde en integreret del af læreprocessen og der opnås en høj grad af validitet i bedømmelsen.

Som et redskab for feedback til underviseren - til kursusevaluering - er de studerendes portfolier - og især deres slutrefleksioner - meget værdifulde, da de tydeligt viser om målene for undervisningen er blevet indfriede.

Portfolioen afspejler arbejdsprocessen og forankrer eksamen i den løbende undervisning. I arbejdspapiret "Eksamensformer: Valg med konsekvenser" skriver Hanne Leth Andersen (2005), at det synes oplagt at denne arbejdsform fremmer de deltagendes engagement, ansvar for egen læringsproces og evne til at bedømme eget arbejde. Dette synspunkt er vi helt enige i. Det er vores mål at øge de studerendes "medejerskabsfølelse” i undervisningen og fremme deres brug af dybdestrategier; det mener vi at portfoliometoden giver et væsentligt bidrag til.

Dybdestrategier (Ramsden, 1999) er læringsstrategier, hvor drivkraften er en vilje til at forstå og lære - ved at den studerende søger at relatere og integrere tidligere erfaringer og viden 
med ny viden. Overfladestrategier er derimod læringsstrategier, hvor den studerendes drivkraft mere er et ønske om med mindst mulig indsats (nok så 'rationelt') at bestå de bedømmelser og eksaminer der er indlagt i undervisningen. Det, der ifølge Ramsden bl.a. kan fremelske dybdestrategier hos de studerende, er, når de oplever undervisningsmetoder, der stimulerer aktive og langvarige engagementer i læringsopgaverne.

Portfolier kan netop benyttes til at støtte sådanne engagerende og længerevarende læringsforløb, da der skabes en kontinuerlig proces, som spredes ud over semestret. og hvor de studerendes refleksioner over egen læring får en central placering.

I de to beskrevne cases, valgte vi almindelige hjemmesider som platform for den virtuelle portfolio, for at give de kommende bibliotekarer mulighed for at at udvikle sidekompetencer i design af websider.

De to forfatteres erfaringer med at bruge portfolio-webs og blogs i undervisningen gør, at netop blogs med deres logbogs-funktion vil blive brugt fremover som et oplagt godt portfolioværktøj, hvor de studerende kan holde styr på refleksioner, delopgaver, ideer og erfaringer og løbende dele dem med underviserne og de andre studerende. Kommentarfelterne i blogs giver desuden gode muligheder for nem og hurtig feedback, både mellem underviser og studerende - og mellem de studerende. Muligheden for at oprette blogs ved hjælp af skabeloner, fx hos www.blogger.com, gør at kravene til webdesign-færdigheder er langt mindre end ved almindelige websider. Det vil være en god sidekompetence at lære at lave blogs, da flere og flere biblioteker laver blogs som kommunikationsmiddel med brugerne.

De nemme muligheder for indlæg, logbogs-funktion, videndeling og feedback gør altså den virtuelle portfolio til et godt bedømmelses- og læringsredskab i undervisningen.

Portfolio-modellen er tidkrævende for alle parter. Det kræver en hel del indsats både af studerende og af undervisere med hensyn til at skrive, læse og give feedback i løbet af hele semestret. Der er også tærskler, der skal overvindes med teknisk og psykologisk karakter. Som det fremgår af de studerendes udsagn i de to cases, gik det hurtigt med at sætte sig ind i det tekniske med at lave websider. Derimod krævede det en del tilvænning at blive så synlige for hinanden, da alle kunne følge med i hinandens portfolier. Dette skabte større forpligtelser i forhold til, hvordan man skulle formulere sig skriftligt i sin portfolio. Til gengæld gav den større gensidige synlighed også de studerende mulighed for at kunne spejle sig i hinanden, og se hvordan andre studerende håndterede refleksioner omkring egen læring, projektvalg, mm.

Den ekstra arbejdsindsats som portfolio-modellen kræver af os som undervisere bliver kompenseret af den tilfredsstillelse, der ligger i, at der er sammenhæng mellem læringsmål, arbejdsformer og bedømmelsesform.

\section{Litteratur}

Biggs, John. Teaching for Quality Learning at University. 2. ed. Buckingham: The Society for Research in Higher Education \& Open University Press, 2003.

Leth Andersen, Hanne. Eksamensformer: Valg af konsekvenser. Arbejdspapir nr. 2005-01. Center for Undervisningsudvikling, Aarhus Universitet, 2005. Online:

<http://www.hum.au.dk/cfu/sider/epublikationer/eksamensformer.pdf> (downloaded 30.5.2006)

Ramsden, Paul. Strategier for bedre undervisning. København: Gyldendal, 1999. 